Note

\title{
Vertical distribution of pico- and nano-sized Dapi yellow particles at Dyfamed time-series station, NW Mediterranean
}

\section{Distribution verticale des particules colorées au Dapi (Dapi yellow particles) de taille pico- et nano-planctonique à la station d'observation permanente Dyfamed en Méditerranée nord-occidentale}

\author{
Tsuneo Tanaka $^{\mathrm{a}, *}$, Fereidoun Rassoulzadegan ${ }^{\mathrm{b}}$ \\ ${ }^{a}$ University of Bergen, Department of Microbiology, Jahnebakken 5, PO Box 7800, 5020 Bergen, Norway \\ ${ }^{b}$ LOV-UMR 7093, Station Zoologique, CNRS-UPMC, B.P. 28, 06234 Villefranche-sur-Mer, France
}

Received 19 September 2002; received in revised form 25 November 2002; accepted 27 November 2002

\begin{abstract}
We measured abundance and surface area of pico- and nano-sized organic particles that are stained by 4'6-diamidino-2-phenylindole (Dapi), namely Dapi yellow particles. This study was done monthly from April 1999 to March 2000 from surface down to $2000 \mathrm{~m}$ at the French-JGOFS time-series station Dyfamed in the NW Mediterranean. Dapi yellow particles were always observed throughout the water column and the total surface area of Dapi yellow particles $0.2-10 \mu \mathrm{m}$ ranged from 0.5 to $51.5 \mathrm{~mm}^{2} \mathrm{l}^{-1}$. Dapi yellow particles were generally less abundant in the surface layer, greater between 70 and $500 \mathrm{~m}$ and decreased toward $2000 \mathrm{~m}$. During the mixing period, Dapi yellow particles were homogeneous throughout the upper $200 \mathrm{~m}$, suggesting that distribution of Dapi yellow particles was influenced by the hydrological structure. Dapi yellow particles correlated positively with inorganic nutrients $\left(\mathrm{NO}_{3}, \mathrm{PO}_{4}\right.$ and $\left.\mathrm{Si}\right)$ and negatively with dissolved oxygen concentration $(P<0.05)$. These results suggest that abundant Dapi yellow particles from the bottom of the euphotic layer to the intermediate layer reflect the process of particle degradation in the ocean.
\end{abstract}

(C) 2003 Éditions scientifiques et médicales Elsevier SAS and Ifremer/CNRS/IRD. All rights reserved.

Résumé

L'abondance des pico- et nano-particules colorées en jaune (Dapi yellow particles) suite au marquage au 4'6-diamidino-2-phénylindole (Dapi) a été mesurée chaque mois, d'avril 1999 à mars 2000, au site Dyfamed (JGOFS-France). Les échantillons ont été collectés de la surface à deux mille mètres de profondeur. Ces particules sont toujours présentes dans la colonne d'eau et dans la zone de surface. Abondance de ces particules, dont la taille est comprise entre 0,2 et $10 \mu \mathrm{m}$, varie de 0,5 à $51,5 \mathrm{~mm}^{2} 1^{-1}$. En général, les Dapi yellow particles sont peu abondantes dans la zone de surface, leur abondance augmentant entre 70 et $500 \mathrm{~m}$ puis diminuant jusqu'à $2000 \mathrm{~m}$. Pendant la période de mélange d'eau, ces particules se répartissent de manière homogène dans la colonne d'eau jusqu'à $200 \mathrm{~m}$, ce qui indique que leur distribution est influencée par la structure hydrologique. La distribution des Dapi yellow particles est positivement corrélée avec la concentration en sels nutritifs $\left(\mathrm{NO}_{3}\right.$, $\mathrm{PO}_{4}$ et $\mathrm{Si}$ ) et négativement corrélée avec la concentration en oxygène dissoute $(p<0,05)$. Ces résultats suggèrent que la forte abondance de ces particules, de la couche euphotique, à la couche intermédiaire est liée aux processus de dégradation des particules dans l'océan.

(c) 2003 Éditions scientifiques et médicales Elsevier SAS and Ifremer/CNRS/IRD. Tous droits réservés.

Keywords: Dapi yellow particles; Organic materials; Detritus; Mediterranean Sea

Mots clés : Dapi yellow particles ; Matériel organique ; Détritus ; Méditerranée occidentale

* Corresponding author

E-mail address: tsuneo.tanaka@im.uib.no (T. Tanaka). 


\section{Introduction}

Dissolved organic carbon (DOC) is one of the largest reservoirs of organic carbon in the global ecosystem (Hedges, 1992). DOC in seawater is operationally defined as the organic carbon that passes through filters (e.g. Whatman GF/F filters). Recent studies have revealed that a large fraction of DOC consists of colloidal and submicrometer particles (Koike et al., 1990; Wells and Goldberg, 1993; Benner et al., 1992). This strongly suggests that small particles play an important role for organic matter transition between soluble and particulate pools. Various small-sized particles were discovered during the last decade (Alldredge et al., 1993; Mostajir et al., 1995a; Long and Azam, 1996). This has led to a hypothesis of the "detritus continuum" in the ocean, in which various sizes of organic matter ranging from dissolved form to large particles are coupled through the processes of particle production and loss (McCave, 1984; Yamasaki et al., 1998).

When 4'6-diamidino-2-phenylindole (Dapi) was introduced as a more specific and sensitive fluorescent probe than acridine orange for counting aquatic bacteria, particles other than Dapi-stained living DNA were reported as invisible or "pale yellow" under an epifluorescence microscope with an ultraviolet excitation filter set (Porter and Feig, 1980). Dapistained yellow particles (DYP) were first described by Mostajir et al. (1995a, b). They reported that :

- more than $90 \%$ of DYP were organic, enzymedegradable matter;

- DYP were abundant and ranged in size from $0.2 \mu \mathrm{m}$ to tens of $\mu \mathrm{m}$;

- DYP were much less abundant in larger size class (ca. $>15 \mu \mathrm{m})$ than smaller size class $(<10 \mu \mathrm{m})$;

- attached bacterial density was much lower on pico- and nano-sized than on micro-sized (>20 $\mu \mathrm{m}$ ) DYP.

Recently, Brachvogel et al. (2001) suggested that DYP in a mesotrophic lake are the remains of detrital particulate organic matter, either directly from senescent chrysophytes and dinoflagellates in surface waters, or from decomposed macroaggregates at greater depth.

In the ocean, biogenic carbon in both dissolved and particulate forms is exported from the euphotic layer into the mesopelagic layer, where most of organic carbon is considered to be remineralized to $\mathrm{CO}_{2}$. Relatively little is known about the fate and loss process of biogenic carbon in the aphotic layer. Although the discussion on origin and fate of DYP are largely open (Simon et al., 2002), DYP are presumably important in process of formation and degradation of organic matter (Mostajir et al., 1995b; Brachvogel et al., 2001; Carrias et al., 2002). However, the data on abundance, size and distribution of DYP in the ocean are still limited. In this paper, we present seasonal distributions of DYP down to $2000 \mathrm{~m}$ at an offshore site in the NW Mediterranean Sea in order to answer the following questions:

- Are DYP ubiquitously distributed down to the bathypelagic layer of the ocean?
- Does DYP distribution show marked variation in space and time?

- How are DYP dynamics related to other chemical and biological parameters?

\section{Materials and methods}

The French-JGOFS time-series station Dyfamed is located in the central zone of the Ligurian Sea, the NW Mediterranean Sea $\left(43^{\circ} 25.2^{\prime} \mathrm{N}, 07^{\circ} 51.8^{\prime} \mathrm{E}\right.$; $2350 \mathrm{~m}$ max depth). A seasonal study was conducted from April 1999 to March 2000. Water samples were generally collected at 13 depths between 5 and $2000 \mathrm{~m}$, using a carousel system equipped with 12-1 Niskin bottles and a conductivity-temperaturedepth profiler (SeaBird SBE 911 plus). Samples for DYP estimation were prepared following Mostajir et al. (1995a). Briefly, particles in water samples were stained with Dapi (final concentration $0.5 \mu \mathrm{g} \mathrm{ml}^{-1}$ ), collected on polycarbonate black filters with $0.2 \mu \mathrm{m}$ pore size, and counted at $1250 \times$ using epifluorescence microscope with an ultraviolet excitation filter set. Because of much lower abundance of DYP $>10 \mu \mathrm{m}$ than that $<10 \mu \mathrm{m}$, we counted only DYP $0.2-10 \mu \mathrm{m}$. DYP size was recorded as the maximum axis length and DYP were grouped into three different size classes $(0.2-2,2-5$ and $5-10 \mu \mathrm{m})$ using a calibrated ocular micrometer. The surface area was calculated assuming that each particle of the above size classes was circular with diameter of $1.25,3.5$ and $7.5 \mu \mathrm{m}$, respectively, by which total surface area of DYP $0.2-10 \mu \mathrm{m}$ per unit water volume was expressed in $\mathrm{mm}^{2} \mathrm{l}^{-1}$.

In order to compare DYP distribution with other chemical and biological parameters, correlation analysis was conducted using the data of dissolved oxygen, inorganic nutrients $\left(\mathrm{NO}_{3}, \mathrm{PO}_{4}\right.$ and $\mathrm{Si}$ ), chlorophyll $a$ (chl-a) (Marty, 2000) and the abundance of microbial components (bacteria, cyanobacteria, heterotrophic and autotrophic nanoflagellates, and ciliates) (Tanaka and Rassoulzadegan, 2002) at the study site. The productive layer is usually limited to the upper $100 \mathrm{~m}$ (Marty and Chiavérini, 2002) and the depthdependent decrease of microbial heterotrophs was significantly different between the 110-500 and the 500-2000 m layers at the study site (Tanaka and Rassoulzadegan, 2002). Therefore, the analysis was done not only for the whole depth but also for three different layers (i.e. 5-110, 110-500 and 500-2000 m).

\section{Results and discussion}

Water temperature and salinity varied from 12.8 to $25.1^{\circ} \mathrm{C}$ and from 37.75 to 38.58 PSU, respectively, in the water column (0-2000 m) during the study period (Marty, 2000). In the surface layer, temperature and salinity showed marked seasonal variations. The stratification started in May 1999, persisted through summer and broke down in November or December 1999. While the Levantine intermediate water from the Eastern Basin flows through very slowly (Béthoux 


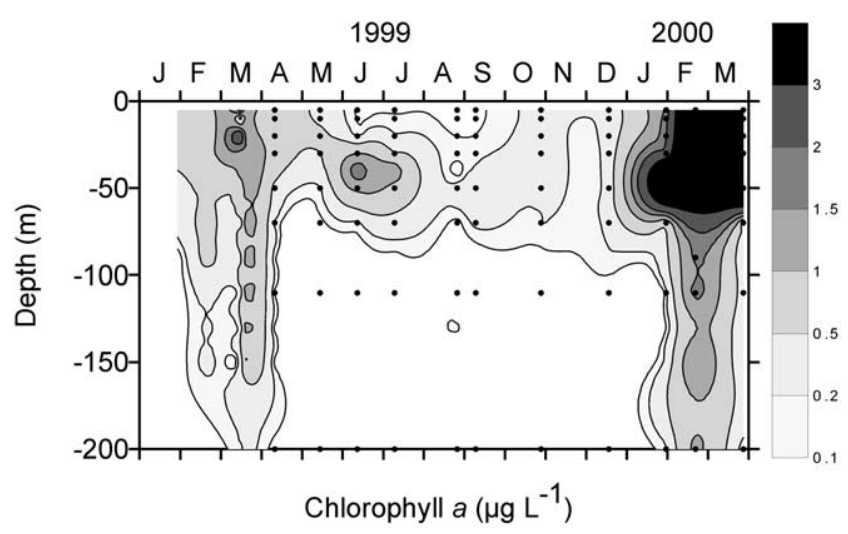

Fig. 1. Seasonal variation of chl-a $\left(\mu \mathrm{g} \mathrm{l}^{-1}\right)$ from January 1999 to March 2000 (Marty, 2000; Dyfamed Observation Service). Dots denote the positions of sampling depths for DYP.

et al., 1988), a different water mass originating from the Levantine intermediate water was observed in the intermediate layer (ca. 200-700 m). The deeper water was colder and less saline than the intermediate water. Dissolved oxygen concentration was highest in the surface $(30-50 \mathrm{~m})$, decreased toward 200-300 m, then increased gradually toward $2000 \mathrm{~m}$ except during the winter mixing period (CopinMontégut and Begovic, 2002).

The spring phytoplankton bloom occurred in March 1999 and higher chl-a values were observed throughout the upper $200 \mathrm{~m}$ Fig. 1). This bloom terminated in April. From May to September 1999, a subsurface chl-a peak was observed below the thermocline (ca. 30-50 m) corresponding to a subsurface maximum of autotrophic nanoflagellate abundance (Tanaka and Rassoulzadegan, 2002).

The surface area of DYP varied vertically and seasonally, and ranged from 0.5 to $51.5 \mathrm{~mm}^{2} \mathrm{l}^{-1}$ Fig. 2). Attached bacteria were rarely observed on DYP in the $0.2-10 \mu \mathrm{m}$ size class. From April to December 1999, DYP were generally low in the surface layer, increased between 70 and $500 \mathrm{~m}$ and tended to decrease toward $2000 \mathrm{~m}$. DYP peaks $\left(>15 \mathrm{~mm}^{2} \mathrm{l}^{-1}\right.$ ) were observed in the surface in May and June, and between 70 and $800 \mathrm{~m}$ from April to August. From September to December, DYP were low through the water column, while relatively high values $\left(>10 \mathrm{~mm}^{2} \mathrm{l}^{-1}\right)$ were observed between 100 and $500 \mathrm{~m}$. In January and February 2000, DYP were abundant (> $15 \mathrm{~mm}^{2} \mathrm{l}^{-1}$ ) and distributed homogenously throughout the upper $200 \mathrm{~m}$.

Based on the DYP measurement from coastal to oceanic areas in NW Mediterranean, Mostajir et al. (1995a) suggested that DYP vary along the trophic gradient. This can explain the great difference in average surface area ( \pm S.E.) of DYP between Villefranche Bay $\left(153 \pm 55 \mathrm{~mm}^{2} \mathrm{l}^{-1}\right.$, Mostajir et al., 1995b) and our study site $\left(11.8 \pm 1.0 \mathrm{~mm}^{2} \mathrm{l}^{-1}\right)$ in the surface layer. The previous studies reported the systematic decreases of DOC, sinking POC fluxes and biomass of microbial heterotrophs with depth (Copin-Montégut and Avril, 1993; Miquel et al., 1994; Tanaka and Rassoulzadegan, 2002). DYP peaks in 70-500 $\mathrm{m}$ layer do not follow the vertical trophic gradient. The non-systematic DYP decrease

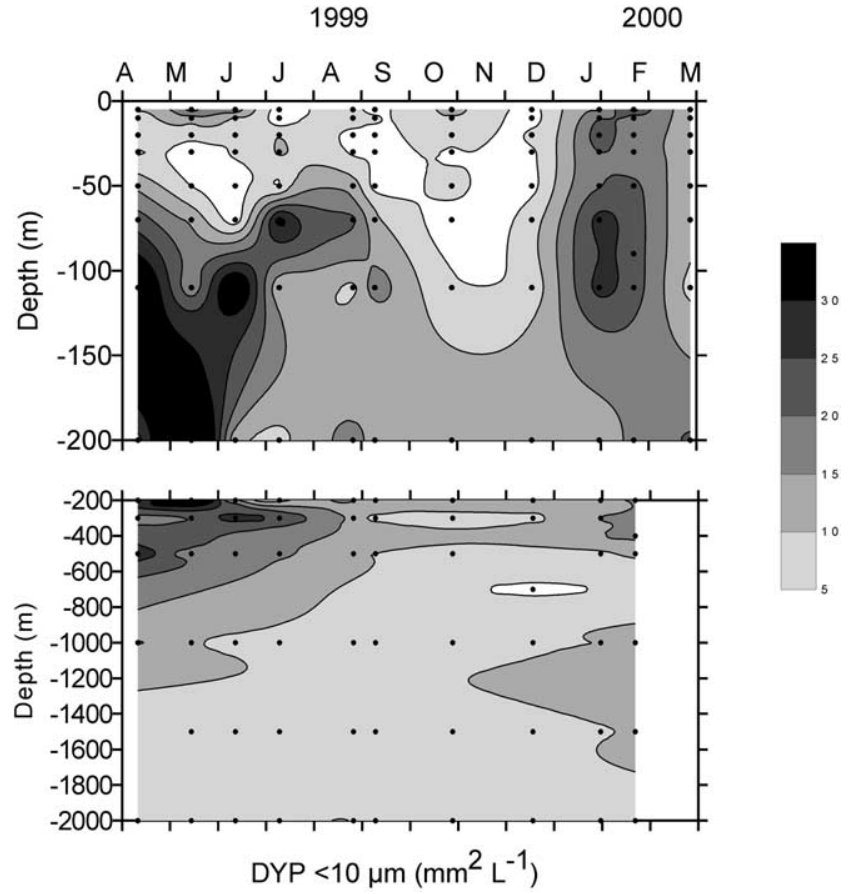

Fig. 2. Spatio-temporal distribution of surface area of DYP $<10 \mu \mathrm{m}$ $\left(\mathrm{mm}^{2} \mathrm{l}^{-1}\right)$ from April 1999 to March 2000. Dots denote the positions of sampling depths for DYP.

with depth is consistent with the recent report from Lake Constance (Brachvogel et al., 2001), which suggests that the balance between formation and degradation of DYP is different from that of other living and non-living organic materials with depth in the water column.

DYP abundance and surface area at each depth are summarized with the other particles measured at the same site Table 1. In the upper $50 \mathrm{~m}$, the abundance of DYP $0.2-10 \mu \mathrm{m}$ was on the order of $10^{5}-10^{6} 1^{-1}$, while transparent exopolymeric particles with nominal size range of 1-100 $\mu \mathrm{m}$ was on the order of $10^{8} 1^{-1}$ (Mari et al., 2001). The seasonal ranges in abundance of DYP, pico- and nanoplankton were one order of magnitude in the upper 500 or $1000 \mathrm{~m}$. While nano-sized DYP were more abundant than nanoplankton in the aphotic layer, pico-sized DYP were always much less abundant than picoplankton.

Correlation analysis showed relatively weak relationships between DYP and the other parameters Table 2). Significant correlations were observed for inorganic nutrients, dissolved oxygen and nanoflagellates for whole depth and for the surface layer. No significant correlation was observed in the intermediate layer. In the deep water, dissolved oxygen and heterotrophic nanoflagellate were correlated to DYP. As in the present study, weak or no relationships were observed between DYP and other parameters, e.g. phytoplankton, chl-a and microbial hetertrophs, in the Mediterranean coastal water (Mostajir et al., 1995b) and in Lake Constance (Brachvogel et al., 2001), perhaps because of a time lag between DYP and other parameters, as was reported for other smallsized particles and macroaggregates (e.g. Alldredge and Gotschalk, 1989; Mari and Burd, 1998). However, the posi- 
Table 1

Annual ranges of pico- and nano-sized DYP, picoplankton (heterotrophic bacteria and cyanobacteria) and nanoplankton (autotrophic and heterotrophic nanoflagellates) at each depth

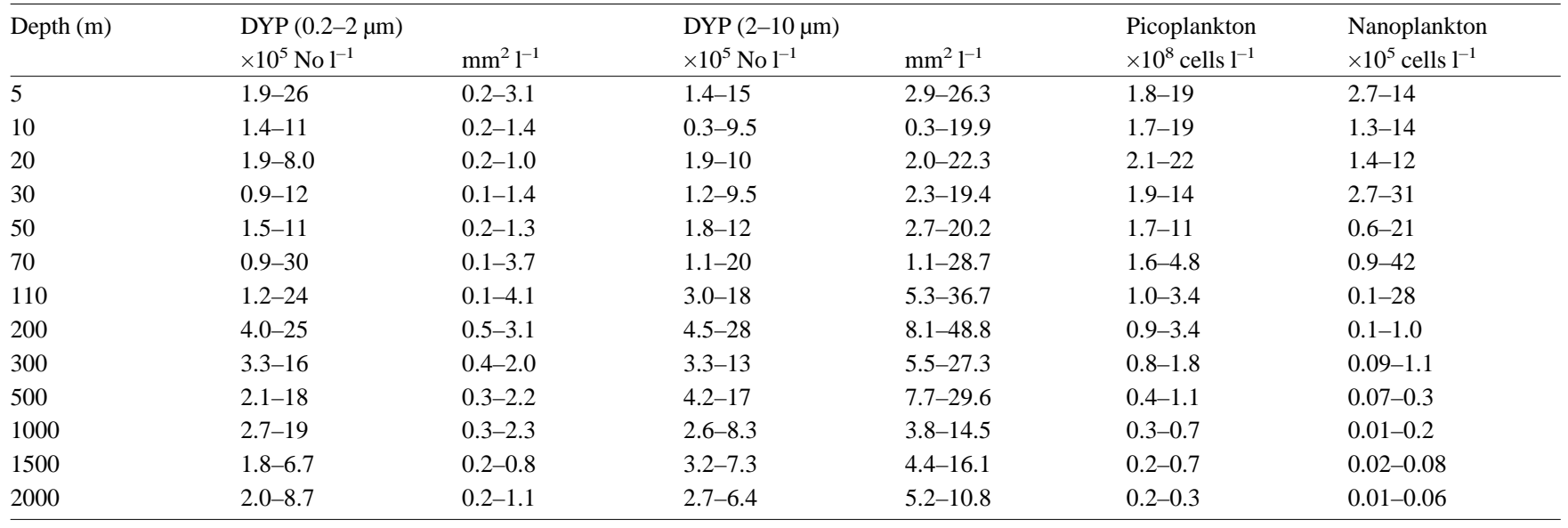

$N=11$ except at 300, 500 and $1500 \mathrm{~m}(N=9), 70,1000$ and $2000 \mathrm{~m}(N=10)$. The data on pico- and nanoplankton from Tanaka and Rassoulzadegan (2002).

tive relationship with inorganic nutrients and the negative relationship with dissolved oxygen suggest that a large portion of DYP is related to regeneration processes at the study site. This supports the suggestion that DYP are derived from decomposed macroaggregates at greater depths (Brachvogel et al., 2001). Also, this is consistent with our observation that bacterivore-free waters from Villefranche Bay with or without nutrient enrichment did not produce DYP during the 20-d incubation (Tanaka, unpublished data).

This study showed that DYP ubiquitously distributed from surface down to $2000 \mathrm{~m}$ at an offshore site in NW Mediterranean and that DYP profiles were weakly correlated with other chemical and biological parameters. Although the origin and fate of DYP need to be more firmly confirmed, our results imply that DYP are related to the regeneration process from the lower part of the euphotic layer to the mesopelgic layer. While net primary production is limited in the euphotic layer, degradation and regeneration processes occur down to mesopelagic layer (e.g. Martin et al., 1987). Relatively higher cell-specific production of particle-associated bacteria (Turley and Stutt, 2000) and the distinct layer of mac- roplanktonic crustacean and fish (Gasser et al., 1998) in the mesopelagic layer of NW Mediterranean may contribute to relatively abundant DYP in 70-500 m layer.

The understanding of the interactions between dissolved and particulate organic matter, between small particles and macroaggregates, and between organic matter and bacteria is essential to improve estimates of oceanic biogenic carbon flux and ocean-atmosphere $\mathrm{CO}_{2}$ exchange (Kepkay, 1994; Simon et al., 2002). DYP could play an important role in carbon cycling in the aphotic zone of the ocean. Quantitative studies of DYP can, therefore, enhance our understanding of the ocean biogeochemistry.

\section{Acknowledgements}

We thank the Dyfamed program and the captains and crews of R/V Téthys II and A. Stock for excellent assistance on the sea. This study was supported by the EC through project "Cyclops" (EVK3-CT-1999-00009). Tsuneo Tanaka was partially supported by the French government as an exchange post-doctoral fellowship for 1998/1999.

Table 2

Correlation analysis between DYP $0.2-10 \mu \mathrm{m}$ vs. chemical and biological parameters measured at the same time. Number of data in parentheses

\begin{tabular}{lllll}
\hline Parameter & Whole period and depth & Surface layer & Intermediate layer & Deeper layer \\
\hline Dissolved oxygen & $-0.267^{* *}(95)$ & $-0.492^{* * *(54)}$ & $0.035(29)$ & $-0.548^{* *}(26)$ \\
$\mathrm{NO}_{3}$ & $0.309^{* * *(135)}$ & $0.585^{* * *}(77)$ & $0.106(40)$ & $0.221(38)$ \\
$\mathrm{PO}_{4}$ & $0.288^{* *}(117)$ & $0.586^{* * *(67)}$ & $0.305(33)$ & $-0.114(33)$ \\
$\mathrm{Si}$ & $0.065(123)$ & $0.414 * * *(70)$ & $0.140(36)$ & $-0.138(35)$ \\
$\mathrm{Chl}-\mathrm{a}$ & $-0.099(81)$ & $-0.018(73)$ & - & - \\
$\mathrm{POC}$ & $-0.186(68)$ & $-0.160(61)$ & - & - \\
$\mathrm{PON}$ & $-0.218(66)$ & $-0.186(59)$ & - & - \\
Bacteria & $-0.116(137)$ & $-0.194(77)$ & $-0.054(41)$ & $0.079(39)$ \\
Cyanobacteria & $-0.137(80)$ & $-0.106(70)$ & - & - \\
Autotrophic nanoflagellates & $-0.257(80)$ & $-0.231(70)$ & - & - \\
Heterotrophic nanoflagellates & $-0.223(125)$ & $-0.360 * *(70)$ & $-0.012(37)$ & $0.438 * *(36)$ \\
Ciliates & $0.039(125)$ & $0.0056(70)$ & $0.003(37)$ & $0.311(36)$
\end{tabular}

*: $P<0.05 ; * *: P<0.01 ; * * *: P<0.001$

The data on dissolved oxygen, nutrients $\left(\mathrm{NO}_{3}, \mathrm{PO}_{4}, \mathrm{Si}\right)$, chlorophyll a (Chl-a), particulate organic carbon and nitrogen (POC, PON) from Marty (2000) (Dyfamed Observation Service), and the data on abundance of microbial components from Tanaka and Rassoulzadegan (2002). 


\section{References}

Alldredge, A.L., Gotschalk, C., 1989. Direct observation of the mass flocculation of diatom blooms: characteristics, settling velocities, and formation of diatom aggregates. Deep-Sea Res. 36, 159-171.

Alldredge, A.L., Passow, U., Logan, B.E., 1993. The abundance and significance of a class of large, transparent organic particles in the ocean. Deep-Sea Res. 40, 1131-1140.

Benner, R., Pakulski, J.D., McCarthy, M., Hedges, J.I., Hatcher, P.G., 1992. Bulk chemical characteristics of dissolved organic matter in the ocean. Science 255, 1561-1564.

Béthoux, J.P., Prieur, L., Bong, J.H., 1988. The Ligurian current off the French Riviera. Oceanol. Acta 9, 59-67.

Brachvogel, T., Schweitzer, B., Simon, M., 2001. Dynamics and bacterial colonization of microaggregates in a large mesotrophic lake. Aquat. Microb. Ecol. 26, 23-35.

Carrias, J.F., Serre, J.P., Sime-Ngando, T., Amblard, C., 2002. Distribution, size, and bacterial colonization of pico- and nano-detrital organic particles (DOP) in two lakes of different trophic status. Limnol. Oceanogr. 47, 1202-1209.

Copin-Montégut, C., Begovic, M., 2002. Distributions of carbonate properties and oxygen along the water column $(0-2000 \mathrm{~m})$ in the central part of the NW Mediterranean (Dyfamed site): influence of winter vertical mixing on air-sea $\mathrm{CO}_{2}$ and $\mathrm{O}_{2}$ exchanges. Deep-Sea Res. 49, 2049-2066.

Copin-Montégut, G., Avril, B., 1993. Vertical distribution and temporal variation of dissolved organic carbon in the North-Western Mediterranean Sea. Deep-Sea Res. 40, 1963-1972.

Gasser, B., Payet, G., Sardou, J., Nival, P., 1998. Community structure of mesopelagic copepods $(>500 \mu \mathrm{m})$ in the Ligurian Sea (Western Mediterranean). J. Mar. Syst. 15, 511-522.

Hedges, J.I., 1992. Global biogeochemical cycles: progress and problems. Mar. Chem. 39, 67-93.

Kepkay, P.E., 1994. Particle aggregation and the biological reactivity of colloids. Mar. Ecol. Prog. Ser. 109, 293-304.

Koike, I., Hara, S., Terauchi, K., Kogure, K., 1990. Role of sub-micrometre particles in the ocean. Nature 345, 242-244.

Long, R.A., Azam, F., 1996. Abundant protein-containing particles in the sea. Aquat. Microb. Ecol. 10, 213-221.

Mari, X., Burd, A., 1998. Seasonal size spectra of transparent exopolymeric particles (TEP) in a coastal sea and comparison with those predicted using coagulation theory. Mar. Ecol. Prog. Ser. 163, 63-76.
Mari, X., Beauvais, S., Lemée, R., Pedrotti, M.L., 2001. Non-Redfield C:N ratio of transparent exopolymeric particles in the northwestern Mediterranean Sea. Limnol. Oceanogr. 46, 1831-1836.

Martin, J.H., Knauer, G.A., Karl, D.M., Broenkow, W.W., 1987. VERTEX: carbon cycling in the northeast Pacific. Deep-Sea Res. 34, 267-285.

Marty, J.-C., 2000, Dyfamed Observation Service. http://www.obsvlfr.fr./jgofs2/sodyf/home.htm.

Marty, J.-C., Chiavérini, J., 2002. Seasonal and interannual variations in phytoplankton production at Dyfamed time-series station, northwestern Mediterranean Sea. Deep-Sea Res. 49, 2017-2030.

McCave, I.N., 1984. Size spectra and aggregation of suspended particles in the deep ocean. Deep-Sea Res. 31, 329-352.

Miquel, J.C., Fowler, S.W., La Rosa, J., Buat-Menard, P., 1994. Dynamics of the downward flux of particles and carbon in the open northwestern Mediterranean Sea. Deep-Sea Res. 41, 243-261.

Mostajir, B., Dolan, J.R., Rassoulzadegan, F., 1995. a. A simple method for the quantification of a class of labile marine pico- and nano-sized detritus: DAPI yellow particles (DYP). Aquat. Microb. Ecol. 9, 259-266.

Mostajir, B., Dolan, J.R., Rassoulzadegan, F., 1995b. Seasonal variations of pico- and nano-detrital particles (DAPI Yellow Particles, DYP) in the Ligurian Sea (NW Mediterranean). Aquat. Microb. Ecol. 9, 267-277.

Porter, K.G., Feig, Y.S., 1980. The use of DAPI for identifying and counting aquatic microflora. Limnol. Oceanogr. 25, 943-948.

Simon, M., Grossart, H.P., Schweitzer, B., Ploug, H., 2002. Microbial ecology of organic aggregates in aquatic ecosystems. Aquat. Microb. Ecol. 28, 175-211.

Tanaka, T., Rassoulzadegan, F., 2002. Full-depth profile (0-2000 m) of bacteria, heterotrophic nanoflagellates and ciliates in the NW Mediterranean Sea: vertical partitioningof microbial trophic structures. Deep-Sea Res. 0 (49), 2093-2107.

Turley, C.M., Stutt, E.D., 2000. Depth-related cell-specific bacterial leucine incorporation rates on particles and its biogeochemical significance in the Northwest Mediterranean. Limnol. Oceanogr. 45, 419-425.

Wells, M.L., Goldberg, E.D., 1993. Colloid aggregation in seawater. Mar. Chem. 40, 5-18.

Yamasaki, A., Fukuda, H., Fukuda, R., Miyajima, T., Nagata, T., Ogawa, H., Koike, I., 1998. Submicrometer particles in northwest Pacific coastal environments: abundance, size distribution, and biological origins. Limnol. Oceanogr. 43, 536-542. 